Засухина Ольга Александровна, доцент, Ангарский государственный технический университет, e-mail: olga_a_z@mail.ru

Алафьева Марина Александровна, обучающаяся, Ангарский государственный технический университет, e-mail: alalafeve@mail.ru

АВТОМАТИЗАЦИЯ РАСЧЕТА ГРАФИКА ПЛАНОВО-ПРЕДУПРЕДИТЕЛЬНОГО РЕМОНТА ЭЛЕКТРООБОРУДОВАНИЯ В СИСТЕМЕ УПРАВЛЕНИЯ БАЗАМИ ДАННЫХ

Zasukhina O.A., Alafeva M. A.

\title{
AUTOMATION OF CALCULATION OF SCHEDULE PREVENTIVE REPAIR OF ELECTRICAL EQUIPMENT IN THE DATABASE MANAGEMENT SYSTEM
}

\footnotetext{
Аннотация. Рассмотрен пример расчета годового графика планово-предупредительного ремонта электрооборудования.

Ключевые слова: график, нормативы, SQL-запрос.

Abstract. An example of calculation of the annual schedule of preventive maintenance of electrical equipment is considered.
}

Keywords: chart, standards, SQL query.

Годовой график планово-предупредительного ремонта электрооборудования является основным документом, по которому осуществляется ремонт электрооборудования. На его основе определяется потребность в ремонтном персонале, в материалах, запасных частях, комплектующих изделиях. В него включается каждая единица, подлежащая капитальному и текущему ремонту электрооборудования. Для его составления необходимы наименование оборудования, нормативы периодичности ремонта электрооборудования, дата последнего текущего и капитального ремонтов. Автоматизированный расчет графика планово-предупредительного ремонта для выбранного электрооборудования в системе управления базами данных позволяет определиться с количеством и видом ремонтов в предстоящем году, годовым простоем в ремонте и годовым фондом рабочего времени.

База данных «Информационное обеспечение процесса ремонта электротехнического оборудования» имеет реляционную модель [1, 2], разработана в настольной системе управления базами данных Microsoft Access [3, 4] и предназначена для автоматизации работы компании, основным направлением деятельности которой является ремонт электротехнического оборудования. Структурированные данные, хранящиеся в таблицах «НАИМЕНОВАНИЕ ОБОРУДОВАНИЯ», «НОРМАТИВЫ ОБОРУДОВАНИЯ» (рисунок 1) являются входными данными для расчета годового графика планово-предупредительного ремонта электрооборудования. Периодичность ремонта и простоя в ремонте электрооборудования определяются в справочных нормативах на ремонт электротех- 
нического оборудования и измеряются в часах. Даты текущего и капитального ремонтов в предстоящем году рассчитываются по формулам с использованием нормативов. Годовой простой в ремонте (в часах) и годовой фонд рабочего времени (в часах) рассчитываются по формулам. С помощью разработанных SQL-запросов на выборку и добавление, в которых реализованы формулы расчета, формируется автоматически выходная таблица ГОДОВОЙ ПЛАНГРАФИК ППР.

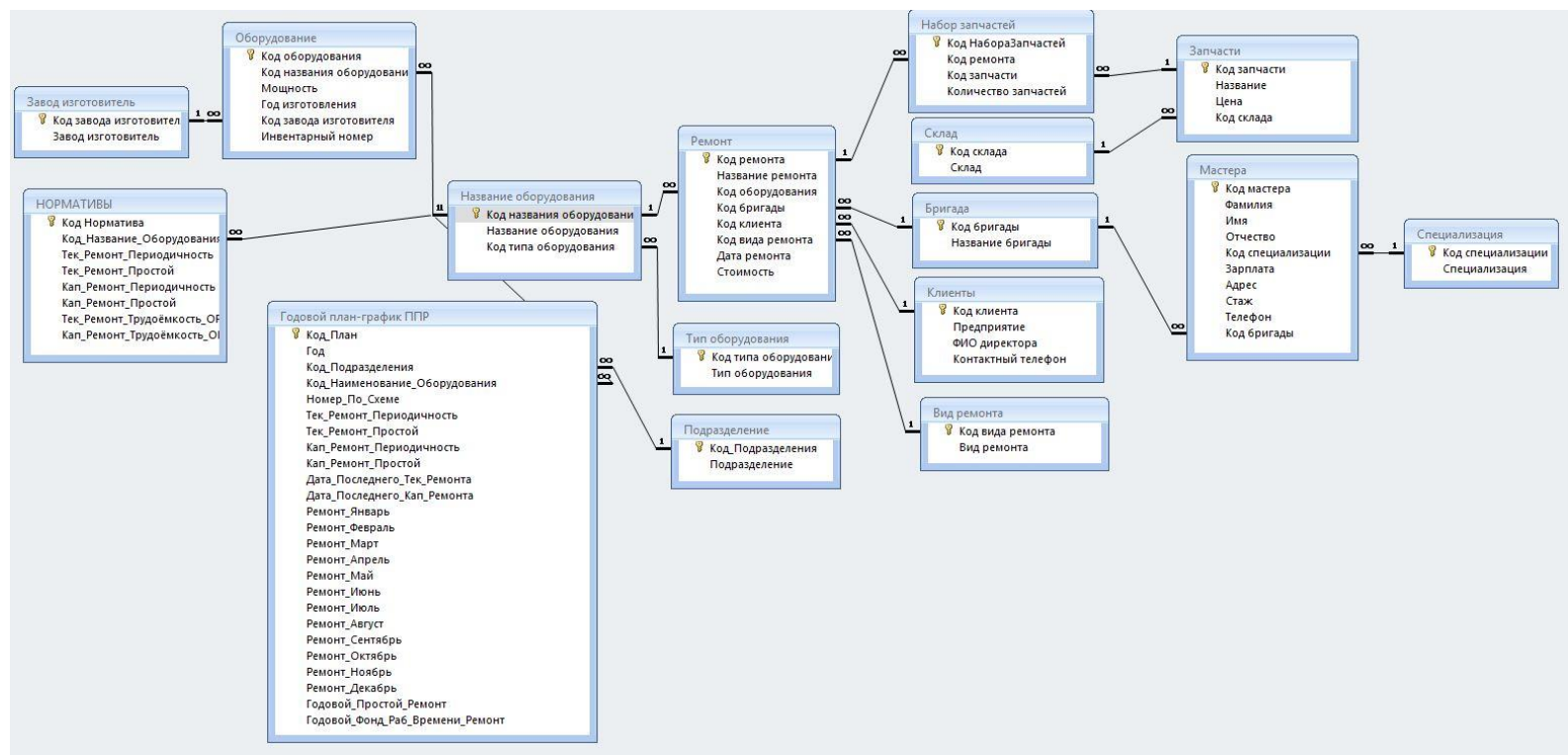

Рисунок 1 - Схема данных базы данных «Информационное обеспечение процесса ремонта электротехнического оборудования»

Автоматизировать расчеты графика планово-предупредительного ремонта электрооборудования в настольной системе управления базами данных Microsoft Access можно удобно в одном файле базы данных, что позволяет увеличить производительность труда.

\section{ЛИТЕРАТУРА}

1. Дубицкий М.А., Засухина О.А. Методические указания по курсовому проектированию по курсу «Информационные технологии в энергетике» / Ангарск: АнГТУ, 2017. - 61с.

2. Засухина О.А. Методические указания и варианты по выполнению лабораторных работ / Ангарск: АГТА, 2014. - 81с.

3. Малыхина М.П. Базы данных: основы, проектирование, использование/ М. П. Малыхина. - 2-е изд., перераб. и доп. - СПб.: БХВ-Петербург, 2006. - 528 с.

4. Базы данных: учеб. пособие/ А.В. Кузин, С.В. Левонисова. - 2-е изд., стереотип. - М.: Академия, 2008. - 320 с. 